African Crop Science Journal by African Crop Science Society is licensed under a Creative Commons Attribution 3.0 Uganda License. Based on a work at www.ajol.info/ and www.bioline.org.br/cs DOI: https://dx.doi.org/10.4314/acsj.v28i2.1

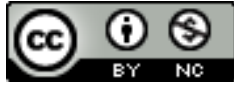

\title{
In vitro SUPPRESSION OF PATHOGENIC FUNGI BY Streptomyces spp.
}

\author{
N. GOREDEMA, T. NDOWORA, R. SHOKO and E. NGADZE ${ }^{1}$
}

Chinhoyi University of Technology, Private Bag 7724, Chinhoyi, Zimbabwe ${ }^{1}$ University of Zimbabwe, P. O. Box MP 167 Mt. Pleasant, Harare, Zimbabwe Corresponding author: nyashaemma@gmail.com

(Received 4 May 2019; accepted 23 June 2020)

\begin{abstract}
The use of living organisms or natural enemies of pathogens to control their populations is called biological disease control. It involves harnessing and introduction of exotic species of microorganism in a natural form, with the intention of controlling pathogens that may exist naturally in the same ecosystem. Prospects for biological control of Aspergillus flavus, Fusarium oxysporum and Penicillium italicum were investigated using Streptomyces spp. isolated from Chinhoyi University of Technology Farm soils in Mashonaland West, Zimbabwe. Twenty seven Streptomyces spp were obtained from the soil, and screened for antimicrobial activity and antagonism in in vitro pathogen inhibition assays, replicated thrice. Although majority of the isolates tested elicited no effect on test pathogens, $22 \%$ of the Streptomyces isolates were able to effectively suppress A. flavus, F. oxysporum and P. italicum by at least 55\%. There was a significant interaction between Streptomyces isolates and pathogen (A. flavus, $F$. oxysporum and P. italicum) $(\mathrm{P}<0.05)$ on fungal radial growth at days 7, 10 and 14 after pathogen-Streptomyces incubation. Antimicrobial potential against individual and multiple test pathogens was observed, with CUT-Streptomyces 4, CUT-Streptomyces 10, CUT-Streptomyces 11, CUT-Streptomyces 20 and CUT-Streptomyces 23 showing the greatest antimicrobial activity. CUTStreptomyces isolates have the potential to suppress A. flavus, F. oxysporum and P. italicum in vitro.
\end{abstract}

Key Words: Aspergillus flavus, Fusarium oxysporum, Penicillium italicum

\section{RÉSUMÉ}

L'utilisation d'organismes vivants ou d'ennemis naturels d'agents pathogènes pour contrôler leurs populations est appelée contrôle biologique des maladies. Il s'agit d'exploiter et d'introduire des espèces exotiques de microorganismes sous une forme naturelle, dans le but de contrôler les agents pathogènes pouvant exister naturellement dans le même écosystème. Les perspectives de lutte biologique contre Aspergillus flavus, Fusarium oxysporum et Penicillium italicum ont été étudiées à l'aide de Streptomyces spp. isolées des sols agricoles de l'Université de Technologie de Chinhoyi à Mashonaland West, Zimbabwe. Vingt-sept Streptomyces spp ont été obtenus du sol et criblés pour l'activité antimicrobienne et l'antagonisme dans des tests d'inhibition des agents pathogènes in vitro, répliqués trois fois. Bien que la majorité des isolats testés ne provoquent aucun effet sur les 
agents pathogènes testés, $22 \%$ des isolats de Streptomyces sont capables de supprimer efficacement au moins 55\% des A. flavus, $F$. oxysporum et $P$. italicum. Il y avait une interaction significative entre les isolats de Streptomyces et l'agent pathogène (A. flavus, F. oxysporum et P. italicum) $(\mathrm{P}<0.05)$ lors de la croissance radiale des champignons aux $7^{\text {ème }}, 10^{\text {ème }}$ et $14^{\text {ème }}$ jours après l'incubation de l'agent pathogène-Streptomyces. Un potentiel antimicrobien contre des agents pathogènes individuels et multiples a été observé. CUT-Streptomyces 4, CUT-Streptomyces 10, CUT-Streptomyces 11, CUTStreptomyces 20 et CUT-Streptomyces 23 ont montré l'activité antimicrobienne la plus élevée. Les isolats de CUT-Streptomyces ont le potentiel de supprimer A. flavus, F. oxysporum et $P$. italicum in vitro.

Mots Clés: Aspergillus flavus, Fusarium oxysporum, Penicillium italicum

\section{INTRODUCTION}

The use of living organisms or natural enemies of pathogens to control their populations is called biological disease control. It involves harnessing and introducing exotic species of microorganism in a natural form, with the intention of controlling pathogens that may exist naturally in the same ecosystem (Mukerji and Chincholkar, 2007). Mechanisms for controlling the pathogens are dependent on the target organisms. The mechanisms include parasitism, antibiosis, hypovirulence, competition for resources, exclusion from niches, plant-growth promotion and induction of systemic acquired resistance in plants; among others (Gupta et al., 2014). Several microorganisms, including Agrobacterium spp., Aspergillus spp., Bacillus spp., Gliocladium spp., Pseudomonas spp., Streptomyces spp. and Trichoderma spp., have been developed into commercial biological control products, against plant diseases (Junaid et al., 2013).

Streptomyces are filamentous Grampositive bacteria that live in diverse environments like soils, water, plants and composts (Hasani et al., 2014). They are well known for their unique characteristic of producing secondary metabolites, such as antibiotics and extracellular enzymes (Inbar $e t$ al., 2005). In soil, Streptomyces produce more than $60 \%$ of clinically useful antibiotics, and are involved in the decomposition of soil organic matter by degrading complex molecules like lignin, lignocellulose, cellulose, xylan and recalcitrant substances (Ding et al., 2004).

Many in vitro and in vivo studies showed that these antinomycetes can be selected for biological control of plant pathogens and promotion of plant growth (Doumbou et al., 2001). These microorganisms possess antagonistic activity against pathogens, a result of their capacity to produce enzymes that have antimicrobial activity, siderophores and antibiotics, among others. Some Streptomyces spp. promote plant growth, through solubilisation of useful phosphates and competion with plant pathogens for nutrients (Cattelan and Hartel, 2000). Several antibiotic producing Streptomyces spp. are used to control various diseases. Some of the diseases include, potato scab caused by Streptomyces scabies (Liu et al., 1995) and post-harvest diseases such as onion bacterial rot disease (Abdallah et al., 2013); banana anthracnose caused by Colletotrichum musae (Ara et al., 2012); and Penicillium digitatum and Geotrichum candidum on lemons (Maldonado, 2010). There are several commercial Streptomyces-based biocontrol products to date, which include Actinovate ${ }^{\circledR}$ (Natural Industries, Inc) and Mycostop ${ }^{\circledR}$ (Verdara Oy, Finland). Furthermore, antibiotics from Streptomyces spp. that have been commercialised into fungicides and bactericides include kasugamycin, validamycin and polyoxin B and D (Doumbou et al., 2001). The objective of this study was to identify Streptomyces isolates with antimicrobial activity for the development of environmentally- 
friendly, biological control disease management strategies.

\section{METHODOLOGY}

Soil sampling. Soil samples were collected from five sites, including a fallow field, an orchard, two anthills, plant residues compost and natural woodland at Chinhoyi University of Technology Farm in Zimbabwe. To collect the samples, the top $4 \mathrm{~cm}$ of soil was scrapped off using a hand hoe to remove any plant or crop residues before collecting the soil residues. A sterilised $15 \mathrm{~cm}$ depth post hole auger was then used to collect soil. A composite sample was made by physically mixing five sub-samples from an area of $1 \mathrm{~m}$ radius at each location, with a clean shovel in a clean plastic bag, and thoroughly homogenised. From the composite sample, five $-150 \mathrm{~g}$ soil samples were taken and placed in sterile poly bags, sealed tightly, stored at 5 ${ }^{\circ} \mathrm{C}$ in a cooler box with ice packs under, and transported to the laboratory for the isolation of Streptomyces.

Isolation of Streptomyces spp. from soil and compost samples. Soil and crop residue compost samples were dried overnight, under three layers of sterile muslin cloth, at room temperature approximately $23{ }^{\circ} \mathrm{C}$. About $5 \mathrm{~g}$ soil or $2 \mathrm{~g}$ of compost was added to $50 \mathrm{ml}$ sterile water in an Erlenmeyer flask, and shaken vigorously at $175 \mathrm{rpm}$ for 60 minutes, on a orbital shaker. Serial dilutions of $10^{-1}$ $10^{-5}$ were each spread on two plates of water agar.

Diluents 50-100 $\mu 1$ were each spread on two plates of water agar. Plates were overlaid with $5 \mathrm{ml}$ of cooled molten starch casein agar (SCA), allowed to solidify and incubated at $28{ }^{\circ} \mathrm{C}$ for 5 days. The serial soil or compost wash dilutions were also plated on oatmeal agar (OA), amended with cycloheximide (50 $\mu \mathrm{ml}^{-1}$ ) to reduce a dense culture of cells to a more usable concentration, and incubated at $28{ }^{\circ} \mathrm{C}$ for 3-5 days. Streptomyces were identified through colony morphological traits. Twenty-seven Streptomyces isolates were selected randomly from the WA-SCA and OA plate, and purified on oatmeal agar by streaking.

In vitro inhibition assays. Individual Streptomyces isolates that grew as pure cultures on OA from WA-SCA and OA were streaked onto OA to produce high density cultures. After 10 days of growth, plugs with mycelium were removed from each plate, using a cork borer $(7-8 \mathrm{~mm})$. Three myceliumcontaining plugs for each isolate were placed equidistant from each other, towards the edge of a fresh potato dextrose agar (PDA) plate; and the plate was sealed with parafilm and incubated for 3 days at $28{ }^{\circ} \mathrm{C}$. Plugs from each Streptomycete isolate were transferred onto nine plates of PDA.

Plugs of growing test pathogens (A. flavus, F. oxysporum and P. italicum) obtained from the Plant Pathology Laboratory, Crop Science Department of the University of Zimbabwe, were each introduced into the centre of each plate so that the inhibition of each pathogen by each Streptomycete isolate could be assessed. Each pathogen-Streptomycete combination was replicated on three plates. The plates were sealed with parafilm and placed at random in an incubator at $28{ }^{\circ} \mathrm{C}$ (Shepherd et al., 2010). Three control plates, each with a different test pathogen, but no Streptomyces isolate, were incubated under the same conditions as the pathogen-Streptomycete plates.

Inhibitory activities of Streptomycete isolates against each of the three pathogens were also determined at days 7, 10 and 14 of pathogenStreptomyces incubation, using a Veneer Callipers, by measuring the growth of the pathogen towards the Streptomycete isolate; and further comparing them to the growth of the fungal pathogen alone using the control. Fungal pathogen radial growth data was recorded in $\mathrm{mm}$ at days 7,10 and 14 of pathogen-Streptomyces incubation. 
Statistical data analysis. Data were subjected to Analysis of Variance using GenStat $14^{\text {th }}$ edition software for windows. Mean comparisons were performed using the Standard Error of the Difference at $\mathrm{P}<0.05$.

\section{RESULTS}

Isolation of Streptomyces spp. strains. Twenty seven, white, cream, yellow, brown or grey colonies which phenotypically appeared to have a relatively smooth surface, but as growth progressed, developed a weft, granular, powdery or velvety aerial mycelium appearance were obtained in pure culture for in vitro inhibition assays.

In vitro inhibition assays. There was a significant effect $(\mathrm{P}<0.05)$ of Streptomyces isolates on the growth of Aspergillus flavus during the A.flavus-Streptomyces incubation period. Aspergillus flavus had a significant effect $(\mathrm{P}<0.05)$ on fungal radial growth at days 7, 10 and 14. There were also interactions $(\mathrm{P}<0.05)$ between Streptomyces isolates and
A. flavus with fungal radial growth at 7, 10 and 14 incubation days (Table 1).

At day 7, radial growth for A. flavus was lowest in combination with CUT-Streptomyces 4, $6 \mathrm{~mm}$ and CUT-Streptomyces 11, $9.67 \mathrm{~mm}$, which translated into radial growth inhibition of 84 and $75 \%$, respectively. These were followed by CUT-Streptomyces 10, CUTStreptomyces 17 and CUT-Streptomyces 20, where A. flavus radial growth was 12.22 , 23.44 and $23.33 \mathrm{~mm}$ compared to the control with a radial growth of $38.67 \mathrm{~mm}$.

On day 10, A. flavus in combination with isolates 4 and 11, had a radial growth of 9.7 $\mathrm{mm}$ and $11.1 \mathrm{~mm}$, respectively. This translated in 77.5 and $74.2 \%$ radial growth inhibition. These were followed by isolate 10 , which inhibited A. flavus radial growth by $67 \%$.

Isolate 4 and 10 had the highest $A$. flavus radial growth inhibition of $64 \%(15.7 \mathrm{~mm}$ fungal growth) and 60\% (17.22 mm fungal growth), respectively, on day 14 . CUTStreptomyces 11 was ranked $3^{\text {rd }}$ with $53 \%$ A. flavus radial growth inhibition.

TABLE 1. Effect of Streptomyces spp. on A. flavus radial growth (mm) at various times of A. flavusStreptomyces incubation

\begin{tabular}{lrrr}
\hline Treatments & Day 7 & Day 10 & Day 14 \\
\hline CUT-Streptomyces 4 & 6 & 9.67 & 15.67 \\
CUT-Streptomyces 10 & 13 & 15 & 18.33 \\
CUT-Streptomyces 11 & 9.67 & 15 & 20.33 \\
CUT-Streptomyces 19 & 26 & 39 & 40.33 \\
CUT-Streptomyces 20 & 23.33 & 41 & 41.33 \\
CUT-Streptomyces 21 & 24.67 & 40 & 41 \\
CUT-Streptomyces 22 & 25.67 & 39 & 41 \\
CUT-Streptomyces 23 & 28.67 & 30.67 & 33 \\
Control & 38.67 & 43 & 43 \\
& & & \\
P value & $<.001$ & $<.001$ & 3.001 \\
\pm s.e.d & 4.708 & 3.911 & 4.6 \\
CV $(\%)$ & 10.9 & 6.4 & \\
\hline
\end{tabular}

Data for some Streptomyces isolates not presented as their performance was more or less similar to the control 
For Fusarium oxysporum, there was a significant effect $(\mathrm{P}<0.05)$ of Streptomyces isolates on the growth for the duration of the F. oxysporum-Streptomyces incubation phase (Table 2). Fusarium oxysporum had a significant effect on fungal radial growth at days 7, 10 and 14. Also, there were interactions $(\mathrm{P}<0.05)$ between Streptomyces isolates and F. oxysporum with fungal radial growth being affected at 7, 10 and 14 assay days (Table 2).

On day 7, CUT-Streptomyces 17 and CUTStreptomyces 7 , in combination with $F$. oxysporum had the highest fungal radial growth inhibition of 74\% (4 mmFusarial growth) and, $68 \%$ (5 mm Fusarial growth), respectively (Table 2). These were succeeded by CUTStreptomyces 20 and CUT-Streptomyces 26, which both had $F$. oxysporum radial growth of $5.67 \mathrm{~mm}$ in comparison to the control $(15.67 \mathrm{~mm})$.

Isolate 26 had the highest $F$. oxysporum radial growth inhibition of $74 \%(7.33 \mathrm{~mm})$ on day 10 (Table 2). This was followed by CUTStreptomyces 20, CUT-Streptomyces 17, CUTStreptomyces 4 and CUT-Streptomyces 24 with F. oxysporum radial growths of 8.7, 9, 10 and $12 \mathrm{~mm}$, correspondingly.

At day 14, isolate 23 had the highest $F$. oxysporum radial growth inhibition of 56\% $(14.7 \mathrm{~mm})$. This was followed by $C U T$ Streptomyces 20, CUT-Streptomyces 4 and CUT-Streptomyces 26 with F. oxysporum radial growths of $15.33,16$ and $15.7 \mathrm{~mm}$, respectively.

TABLE 2. Effect Streptomyces spp. on F. oxysporum radial growth (mm) at various times of $F$. oxysporum-Streptomyces incubation

\begin{tabular}{|c|c|c|c|}
\hline Treatments & Day 7 & Day 10 & Day 14 \\
\hline CUT-Streptomyces 2 & 11 & 15 & 17.67 \\
\hline CUT-Streptomyces 4 & 7.33 & 10 & 16 \\
\hline CUT-Streptomyces 6 & 10.67 & 12 & 22 \\
\hline CUT-Streptomyces 7 & 5 & 13.33 & 25.67 \\
\hline CUT-Streptomyces 9 & 12 & 19 & 26 \\
\hline CUT-Streptomyces 10 & 4.67 & 14.33 & 18.33 \\
\hline CUT-Streptomyces 11 & 7.33 & 13.33 & 19.33 \\
\hline CUT-Streptomyces 17 & 4 & 9 & 18.33 \\
\hline CUT-Streptomyces 20 & 5.67 & 8.67 & 15.33 \\
\hline CUT-Streptomyces 21 & 13.33 & 20.33 & 30 \\
\hline CUT-Streptomyces 22 & 9.33 & 16.67 & 31.67 \\
\hline CUT-Streptomyces 23 & 11.67 & 14.67 & 14.67 \\
\hline CUT-Streptomyces 24 & 10.33 & 12 & 17.33 \\
\hline CUT-Streptomyces 25 & 10 & 13.67 & 22.33 \\
\hline CUT-Streptomyces 26 & 5.67 & 7.33 & 15.67 \\
\hline CUT-Streptomyces 27 & 11.33 & 20 & 21 \\
\hline Control & 15.67 & 29.67 & 33.33 \\
\hline$P$ value & $<.001$ & $<.001$ & $<.001$ \\
\hline \pm s.e.d & 1.628 & 1.247 & 1.288 \\
\hline $\mathrm{CV}(\%)$ & 10.9 & 6.4 & 4.6 \\
\hline
\end{tabular}

Data for some Streptomyces isolates not presented as their performance was more or less similar to the control 
There was a significant effect $(\mathrm{P}<0.05)$ of Streptomyces isolates on growth of P. italicum throughout the $P$. italicum-Streptomyces incubation stages (Table 3). Penicillium italicum had a significant effect $(\mathrm{P}<0.05)$ on fungal radial growth also at 7, 10 and 14 in vitro assay days. There were interactions $(\mathrm{P}<0.05)$ between Streptomyces and $P$. italicum with fungal radial growth being affected at days 7, 10 and 14 (Table 3).

At day 7, radial growth for P. italicum was the lowest in combination with isolates 2 and 8 . These elicited fungal radial growth inhibition of $65 \%$ ( $3 \mathrm{~mm}$ fungal growth). These were trailed by CUT-Streptomyces 10, CUTStreptomyces 11 and CUT-Streptomyces 22 with $P$. italicum radial growth of $3.33,3.33$ and $3.67 \mathrm{~mm}$, respectively.
CUT-Streptomyces 14 and CUTStreptomyces 19 had the highest reduction in fungal pathogen growth of $56 \%(6.33 \mathrm{~mm}$ Penicillium growth) at day 10 (Table 3 ). These were followed on by CUT-Streptomyces 4, CUT-Streptomyces 22 and CUT-Streptomyces 20 with $P$. italicum radial growth of $6.7,7.3$ and $7.7 \mathrm{~mm}$, respectively.

On day 14, CUT-Streptomyces 10, CUTStreptomyces 23 and CUT-Streptomyces 25 had the highest $P$. italicum radial growth inhibition of $51 \%(8 \mathrm{~mm}), 45 \%(9 \mathrm{~mm})$ and $45 \%$ (9 $\mathrm{mm})$, respectively, at day 14 . Ranked $4^{\text {th }}$ and $5^{\text {th }}$ were CUT-Streptomyces 14 and CUTStreptomyces 17 with P. italicum radial growth of 9.333 and $9.887 \mathrm{~mm}$, respectively.

Overall, data showed that CUTStreptomyces 4 and CUT-Streptomyces 10 were

TABLE 3. Effect Streptomyces spp. on P. italicum radial growth ( $\mathrm{mm})$ at various times of $P$. italicumStreptomyces incubation

\begin{tabular}{lrrr}
\hline Treatments & Day 7 & Day 10 & Day 14 \\
\hline CUT-Streptomyces 2 & 3 & 11.67 & 12.333 \\
CUT-Streptomyces 4 & 4 & 6.67 & 13.667 \\
CUT-Streptomyces 8 & 3 & 11 & 14.333 \\
CUT-Streptomyces 10 & 3.33 & 7.33 & 8 \\
CUT-Streptomyces 11 & 3.33 & 8 & 12.333 \\
CUT-Streptomyces 12 & 4.33 & 11 & 13 \\
CUT-Streptomyces 14 & 5.33 & 6.33 & 9.333 \\
CUT-Streptomyces 15 & 4.33 & 11.67 & 11.667 \\
CUT-Streptomyces 17 & 8 & 10.33 & 9.887 \\
CUT-Streptomyces 18 & 7 & 9 & 13 \\
CUT-Streptomyces 19 & 4 & 6.33 & 13 \\
CUT-Streptomyces 20 & 4 & 7.67 & 13 \\
CUT-Streptomyces 22 & 3.33 & 7.33 & 11.667 \\
CUT-Streptomyces 23 & 8.67 & 9 & 9 \\
CUT-Streptomyces 25 & 3.67 & 9 & 9 \\
CUT-Streptomyces 26 & 7 & 9 & 13 \\
Control & 8.67 & 14.33 & 16.333 \\
& & & \\
P value & $<.001$ & $<.001$ & $<.001$ \\
\pm s.e.d & 0.964 & 6.411 & 4.6 \\
CV(\%) & 10.9 & &
\end{tabular}

Data for some Streptomyces isolates not presented as their performance was more or less similar to the control 
the highest performers in inhibiting A. flavus growth (Table 1). CUT-Streptomyces 2, CUTStreptomyces 20 and CUT-Streptomyces 4 had the highest $F$. oxysporum growth. On $P$. italicum growth, CUT-Streptomyces 10, CUTStreptomyces 23 and CUT-Streptomyces 25 had the highest inhibitory activity against the pathogen. Across all fungal pathogens, CUTStreptomyces 2, CUT-Streptomyces 4, CUTStreptomyces 10 and CUT-Streptomyces 23 performed the best. Additionally, Streptomyces had the highest growth reduction on A. flavus as compared to other fungal species tested.

\section{DISCUSSION}

Effect of Streptomyces spp. on A. flavus radial growth. CUT-Streptomyces 11 and CUT-Streptomyces 4 showed the highest antagonism to A. flavus at days 7 and 10 (Table 1). These bacterial isolates in particular had a significant reduction in A. flavus growth by more than $74 \%$ compared to the control. This suggests that these isolates (11 and 4) are quick producers of secondary metabolites (antibiotics) that control fungal plant pathogens (Golinska and Dahm, 2013). Secondary metabolites production enhances antifungal activity, suppressing pathogenic plant diseases (El-Tarabily and Sivasithamparam, 2006; de Vasconcellos and Cardoso, 2009). However, because some Streptomyces colonies were slow-growing and that the production of secondary metabolites by Streptomyces usually corresponds with the aerial hyphae stage of development (Kieser et al., 2000), CUTStreptomyces 10 ranked lower initially, but was able to surpass the antimicrobial performance of many other CUT-Streptomyces isolates by day 14 .

Effect of Streptomyces spp. on $\boldsymbol{F}$. oxysporum radial growth. CUT-Streptomyces 7, CUTStreptomyces 10, CUT-Streptomyces 17, CUTStreptomyces 20 and CUT-Streptomyces 26 exhibited the highest $F$. oxysporum antimicrobial activity at days 7 and 10 (Table 2). Van Driesche (1996) highlighted that
Streptomyces have the ability to compete with the pathogen for nutrients and space. It was observed that CUT-Streptomyces 17, CUTStreptomyces 7 and CUT-Streptomyces 10 grew faster than the fungal pathogen, thus depriving the fungus of nutrients and space. Research by Couteaudier and Alabouvette (1990) showed that when actinomycetes and fungal pathogens coexist in the same environment, they compete for minor elements, for instance, iron. In the present study, CUTStreptomyces isolates deprived $F$. oxysporum of $\mathrm{FeSO}_{4}, \mathrm{MnCl}_{2}$ and $\mathrm{ZnSO}_{4}$, which were amended in assay plates. By depriving $F$. oxysporum of these micro nutrients, CUTStreptomyces were able to reduce the growth of the fungal pathogen.

Streptomyces species have the ability to secrete iron-binding ligands, called siderophores, having high affinity to sequester iron from the micro-environment ( $\mathrm{Pal}$ et al., 2006). This deprives iron from other organisms, hence indirectly causing biological control of such organisms (Boukhalfa and Crumbliss, 2002).

At day 14, CUT-Streptomyces 23, CUTStreptomyces 26, CUT-Streptomyces 20 and CUT-Streptomyces 4 had the highest $F$. oxysporum radial growth reduction by more than $50 \%$ (Table 2). Our observations show that these Streptomyces isolates are able to surround the fungus and appear to be degrading it.

Mycelium holes, disrupted and irregular growth patterns of $F$. oxysporum in in vitro pathogen inhibitory assays revealed that Streptomyces degraded the fungus (Table 2), similar to findings in a study by Patil (2010) on Streptomyces toxytricini antagonist activity against Rhizoctonia solani. The present study confirmed that Streptomyces are principal among actinomycetes that produce antifungal compounds and those that exhibit antagonistic potential against pathogens (Patil et al., 2010; Kaur et al., 2013).

Effect of Streptomyces spp. on P. italicum radial growth. Our results have shown that 
CUT-Streptomyces and P. italicum have a significant interaction $(\mathrm{P}<0.05)$ on fungal pathogen radial growth at days 7, 10 and 14 (Table 3). It was observed that different $C U T$ Streptomyces isolates controlled $P$. italicum across the pathogen-Streptomyces inhibition time series. Observations were also made that $P$. italicum grew much slower; some CUTStreptomyces isolates would grow quickly and cover assay plates before the fungus would establish itself. This may have been attributed to enzyme-producing Streptomyces which have the ability to destroy oospores of phytopathogenic fungi (El-Tarabily, 2006) and affect the spore germination and germ-tube elongation of phytopathogenic fungi (Rothrock and Gottlieb, 1984; Frankowski et al., 2001).

CUT-Streptomyces 2, CUT-Streptomyces 8, CUT-Streptomyces 10 and CUT-Streptomyces 14 were the best performers (Table 3). Earlier studies by El-Tarabily (2006) reported that Streptomyces had the capacity to produce extracellular cell wall degrading enzymes, which in turn were associated with biocontrol abilities of the producing bacteria. Such Streptomyces protect plants from plant pathogenic diseases, through antagonism mechanism of production of lytic enzymes such as glucanases, proteases, cellulases, and chitinases (Dunne, 1997). Through production of these enzymes, bacteria parasitise disease causing fungi.

\section{ACKNOWLEDGEMENT}

This research was funded by Chinhoyi University of Technology, through the Vice Chancellors Excellence Award. We thank the Department Plant Pathology, University of Zimbabwe for providing laboratory facilities and materials for this work.

\section{REFERENCES}

Abdallah, M.E., Haroun, S.A., Gomah, A.A., El-Naggar, N.E. and Badr, H.H. 2013. Application of actinomycetes as biocontrol agents in the management of onion bacterial rot diseases. Archives of Phytopathology and Plant Protection 46(15):1797-1808.

Ara, I., Rizwana, H., Al-Othman, M.R. and Bakir, M.A. 2012. Studies of actinomycetes for biological control of Colletotrichum musae pathogen during post harvest anthracnose of banana. African Journal of Microbiology Research 6(17):3879-3886.

Boukhalfa, H. and Crumbliss, A.L. 2002. Chemical aspects of siderophore mediated iron transport. Biometals 15(4):325-339.

Cattelan, A.J. and Hartel, P.G. 2000. Traits associated with plant growth-promoting rhizobacteria (PGPR). Tópicos em Ciência do Solo, Campinas 1(1):213-234.

Couteaudier, Y. and Alabouvette, C. 1990. Quantitative comparison of Fusarium oxysporum competitiveness in relation to carbon utilization. FEMS Microbiology Letters 74(4):261-267.

Ding, C.H., Jiang, Z.Q., Li, X.T., Li, L.T. and Kusakabe, I. 2004. High activity xylanase production by Streptomyces olivaceoviridis E-86. World Journal of Microbiology and Biotechnology 20(1):7-10.

Doumbou, C.L., Hamby Salove, M.K., Crawford, D.L. and Beaulieu, C. 2001. Actinomycetes, promising tools to control plant diseases and to promote plant growth. Phytoprotection 82(3):85-102.

de Vasconcellos, R.L.F. and Cardoso, E.J.B.N. 2009. Rhizospheric streptomycetes as potential biocontrol agents of Fusarium and Armillaria pine rot and as PGPR for Pinus taeda. Biocontrol 54(6):807.

Dunne, C., Crowley, J.J., Moënne-Loccoz, Y., Dowling, D.N. and O'Gara, F. 1997. Biological control of Pythium ultimum by Stenotrophomonas maltophilia W81 is mediated by an extracellular proteolytic activity. Microbiology 143(12):3921-3931.

El-Tarabily, K.A. and Sivasithamparam, K. 2006. Non-streptomycete actinomycetes as biocontrol agents of soil-borne fungal plant pathogens and as plant growth promoters. Soil Biology and Biochemistry 38(7): 1505-1520. 
Frankowski, J., Lorito, M., Scala, F., Schmid, R., Berg, G. and Bahl, H. 2001. Purification and properties of two chitinolytic enzymes of Serratia plymuthica HRO-C48. Archives of Microbiology 176(6):421-426.

Golinska, P. and Dahm, H. 2013. Antagonistic properties of Streptomyces isolated from forest soils against fungal pathogens of pine seedlings. Dendrobiology 69:87-97.

Gupta, S.K., Gupta, A.K., Sharma, N. and Parasad, D. 2014. Biological control of plant diseases. Approaches and trends in plant disease management. doi.org/10.1007/9783-319-27312-9

Hasani, A., Kariminik, A. and Issazadeh, K. 2014. Streptomycetes: Characteristics and their antimicrobial activities. International Journal of Advanced Biological and Biomedical Research 2:63-75.

Inbar, E., Green, S.J., Hadar, Y. and Minz, D. 2005. Competing factors of compost concentration and proximity to root affect the distribution of streptomycetes. Microbial Ecology 50(1):73-81.

Junaid, J.M., Dar, N.A., Bhat, T.A., Bhat, A.H. and Bhat, M.A. 2013. Commercial biocontrol agents and their mechanism of action in the management of plant pathogens. International Journal of Modern Plant \& Animal Sciences 1(2):3957.

Kieser, T., Bibb, M.J., Buttner, M. J., Chater, K.F. and Hopwood, D.A. 2000. Practical Streptomyces Genetics 59. The John Innes Foundation, Norwich, UK.

Liu, D., Anderson, N.A. and Kinkel, L.L. 1995. Biological control of potato scab in the field with antagonistic Streptomyces scabies. Phytopathology 85(7):827-831.

Maldonado, M.C., Orosco, C. E.F., Gordillo, M. and Navarro, A.R. 2010. In vivo and in vitro antagonism of Streptomyces sp. RO3 against Penicillium digitatum and Geotrichum candidum. African Journal of Microbiology Research 4:2451-2556.

Mukerji, K.G. and Chincholkar, S.B. 2007. Biological control of plant diseases. Food Products Press. Binghamton, USA.

Pal, K.K. and Gardener, B.M. 2006. Biological control of plant pathogens. Plant Health Instructor. doi:10.1094/PHI-A-20061117-02.

Patil, H.J., Srivastava, A.K., Kumar, S., Chaudhari, B.L. and Arora, D.K. 2010. Selective isolation, evaluation and characterization of antagonistic actinomycetes against Rhizoctonia solani. World Journal of Microbiology and Biotechnology 26(12):2163-2170.

Rothrock, C. S. and Gottlieb, D. 1984. Role of antibiosis in antagonism of Streptomyces hygroscopicus var. geldanus to Rhizoctonia solani in soil. Canadian Journal of Microbiology 30(12):1440-1447.

Scala, F., Raio, A., Zoina, A., Lorito, M., Chincholkar, S. and Mukerji, K. 2007. Biological control of fruit and vegetable diseases with fungal and bacterial antagonists: Trichoderma and Agrobacterium. pp. 150-190. In: Chincholkar, S.B. and Mukerji, K.G. (Eds.), Biological control of plant diseases. Binghamton: Howorth Press. USA.

Shepherd, M.D., Kharel, M.K., Bosserman, M.A. and Rohr, J. 2010. Laboratory maintenance of Streptomyces species. Current Protocols in Microbiology 18(1): 10E-1.

Van Driesche, R.G. and Bellows, T.S. 1996. Biological control agents for plant pathogens. pp. 93-101. In: Biological Control. Springer, Boston, MA. USA. 